DOI: https://doi.org/10.47405/mjssh.v5i6.426

\begin{tabular}{|c|c|}
\hline sist & Malaysian Journal of Social Sciences and Humanities (MJSSH) \\
\hline $\begin{array}{l}\text { Malaysian Journal of } \\
\text { Solaci Isciences and }\end{array}$ & Volume 5, Issue 6, June 2020 \\
\hline $\begin{array}{l}\text { Humantites } \\
\text { (MJ-ssH) }\end{array}$ & e-ISSN : 2504-8562 \\
\hline & $\begin{array}{l}\text { Journal home page: } \\
\text { www.msocialsciences.com }\end{array}$ \\
\hline
\end{tabular}

\title{
Kemurungan dan Keamatan Sokongan Sosial dengan Kepuasan Hidup dalam kalangan Pelajar Universiti di Malaysia
}

\author{
Nur Hannan Binti Lokman1, Zanariah Binti Ismail1 \\ 1Jabatan Pembangunan Manusia dan Pengajian Keluarga, Fakulti Ekologi Manusia, \\ Universiti Putra Malaysia (UPM)
}

Correspondence: Zanariah Binti Ismail (zanariah_i@upm.edu.my)

\begin{abstract}
Abstrak
Kajian ini bertujuan untuk menentukan perkaitan antara kemurungan dan keamatan sokongan sosial (keluarga, kawan, orang yang penting) dengan kepuasan hidup dalam kalangan pelajar universiti awam di Selangor, Malaysia. Terdapat 368 orang pelajar yang terlibat dalam kajian ini yang telah dipilih melalui teknik persampelan rawak mudah. Tiga alat pengukuran telah digunakan iaitu Beck Depression Inventory oleh Beck et al. (1961) untuk mengukur kemurungan, Multidimensional Scale of Perceived Social Support oleh Zimet et al. (1988) mengukur keamatan sokongan sosial (keluarga, kawan, orang yang penting) dan kepuasan hidup diukur dengan Satisfaction With Life Scale yang dibangunkan oleh Diener et al. (1985). Hasil kajian menunjukkan bahawa kemurungan mempunyai perkaitan signifikan negatif dengan kepuasan hidup $(\mathrm{r}=-0.598, \mathrm{p}=0.000)$. Selain itu, ketiga-tiga jenis keamatan sokongan sosial iaitu sokongan keluarga, sokongan kawan dan sokongan orang yang penting mempunyai perkaitan signifikan dengan kepuasan hidup $(\mathrm{r}=0.534, \mathrm{p}=0.000),(\mathrm{r}=0.399, \mathrm{p}=0.000)$ dan $(\mathrm{r}=$ $0.421, \mathrm{p}=0.000)$ masing- masing. Tambahan lagi, hasil kajian menunjukkan bahawa tiada perbezaan signifikan antara faktor jantina dengan kepuasan hidup. Kesimpulannya, hasil kajian ini menjelaskan bahawa pentingnya hubungan sosial antara keluarga dan orang sekeliling supaya tidak cenderung ke arah kemurungan seterusnya meningkatkan kepuasan hidup.
\end{abstract}

Kata kunci: kepuasan hidup, kemurungan, keamatan sokongan sosial, pelajar universiti

\section{Depression and Perceived Social Support with Life Satisfaction Among University Students in Malaysia}

\begin{abstract}
This study aimed to determine the relationship between depression and perceived social support (family, friends, significant others) with life satisfaction among public university students in Selangor, Malaysia. There were a total of 368 students participated in this study were randomly selected using simple random sampling. Three instruments were used namely, Beck Depression Inventory by Beck et al. (1961) to measure depression, Multidimensional Scale of Perceived Social Support by Zimet et al (1988) to measure the perceived social support (family, friends, significant other) and life satisfaction were measured by Satisfaction With Life Scale by Diener et al. (1985). The findings demonstrated that depression was negatively correlated with life satisfaction $(\mathrm{r}=-0.598, \mathrm{p}=0.000)$. In addition, the three types of social support which is family support, friends support and significant other were positively correlated with life satisfaction $(r=0.534, p=0.00),(r=0.399, p=0.000)$ dan $(r=0.421, p=0.000)$ respectively. Furthermore, the finding showed there were no significant difference between gender and
\end{abstract}


life satisfaction. In conclusion, the findings of this study explained the importance of social relationships between families and the environment so that it not lead to depression and life satisfaction increased.

Keywords: life satisfaction, depression, perceived social support, university students

\section{Pengenalan}

Pada era globalisasi kini, semua orang mengimpikan kehidupan yang ideal. Definisi kehidupan yang ideal bagi setiap individu adalah berbeza bergantung kepada tahap kepuasan hidup masing-masing. Mempunyai sebuah keluarga, wang yang cukup untuk menyara kehidupan, kesihatan yang stabil adalah memadai bagi sesetengah individu untuk berasa puas dengan hidup mereka. Bagi sesetengah orang pula, selagi mereka tidak mencapai semua keinginan dan kehendak mereka, selagi itu mereka tidak berasa puas. Diener, Emmons, Larsen dan Griffin (1985) mendefinisikan kepuasan hidup sebagai penilaian menyeluruh terhadap kualiti kehidupan seseorang berdasarkan kriteria yang telah ditetapkan oleh seseorang individu itu sendiri.

Perkara ini bermaksud seseorang akan berasa puas atau menilai kehidupan mereka dengan nilai yang tinggi jika kehidupan mereka seperti yang diingini. Kepuasan hidup dan penilaian afektif merupakan terma kesejahteraan subjektif yang merujuk kepada penilaian seseorang terhadap kehidupan mereka termasuk penilaian kognitif (Kapur \& Khosla, 2013). Hal ini menyatakan bahawa kepuasan hidup merupakan komponen kesejahteraan subjektif seseorang individu yang merujuk kepada apa yang mereka fikirkan atau membuat penilaian tentang hidup mereka.

Ramai penyelidik telah menjalankan kajian mengenai faktor yang mempunyai perkaitan dengan kepuasan hidup seseorang individu. Setiap individu mempunyai faktor yang berbeza yang mempengaruhi kepuasan hidup mereka. Bagi seorang pelajar universiti, impian untuk menggenggam segulung ijazah telah menjadi impian setiap pelajar. Pada masa yang sama, mereka mahu mencapai segala keinginan dan kehendak mereka. Berjaya dalam pelajaran dan berseronok adalah antara perkara yang ingin dicapai oleh pelajar universiti. Kepuasan hidup mereka boleh bertambah jika mereka boleh mencapai perkara tersebut. Namun begitu, sejak dari dahulu lagi, kajian mengenai kepuasan hidup banyak disumbangkan oleh penyelidik dari Barat dan Amerika Syarikat (Hadi, 2011). Dalam skop Malaysia, kebanyakan kajian mengenai kesejahteraan lebih memfokuskan kepada kesejahteraan objektif (Ramli, Samah, Samah, Idris, \& Shaffril, 2017).

Dalam pada itu, pelajar universiti merupakan sekumpulan individu yang sedang melalui umur peralihan antara remaja dan dewasa (Bukhari \& Saba, 2017). Mereka perlu menghadapi cabaran dalam kehidupan seperti tinggal berjauhan daripada keluarga, menyesuaikan diri dengan orang yang tidak kenal dan banyak lagi. Pada masa yang sama, mereka boleh terdedah kepada pelbagai punca tekanan. Punca-punca tekanan ini jika tidak ditangani dengan baik boleh membawa kepada kemurungan seterusnya menjejaskan kepuasan hidup. Kajian yang dilakukan oleh Beutel et al. (2010) mendapati bahawa kemurungan merupakan faktor yang mempengaruhi kepuasan hidup. Perkara ini disokong oleh Bukhari dan Saba (2017) yang menyatakan bahawa kemurungan, kebimbangan dan tekanan mempunyai kesan negatif ke atas kesejahteraan dan berkait rapat dengan kepuasan hidup dalam kalangan pelajar universiti.

Selain itu, keamatan sokongan sosial amat diperlukan dalam menghadapi cabaran dalam hidup. Keamatan sokongan sosial boleh dianggap sokongan moral daripada orang sekeliling terutamanya orang terdekat seperti keluarga dan kawan-kawan. Kepuasan hidup boleh ditingkatkan melalui keamatan sokongan sosial. Hal ini demikian kerana, bagi seseorang individu, sokongan sosial amat diperlukan terutamanya ketika mereka menghadapi masalah dan memerlukan orang yang rapat bagi mendengar masalah mereka. Tambahan lagi, kajian yang dilakukan oleh Nabavi dan Bijandi (2018) mendapati bahawa keamatan sokongan sosial merupakan faktor peramal kepuasan hidup yang paling 
kuat. Oleh itu, kajian ini dilakukan untuk menentukan perkaitan antara kemurungan, keamatan sokongan sosial dan kepuasan hidup dalam kalangan pelajar universiti di Malaysia.

\section{Objektif}

1. Untuk memerihalkan latar belakang responden (umur, jantina, bangsa, tahun pengajian, fakulti), tahap kemurungan, tahap keamatan sokongan sosial (sokongan keluarga, sokongan kawan, sokongan orang yang penting) dan tahap kepuasan hidup dalam kalangan pelajar.

2. Untuk menentukan perkaitan antara kemurungan dan keamatan sokongan sosial (sokongan keluarga, sokongan kawan, sokongan orang yang penting) dengan kepuasan hidup dalam kalangan pelajar.

3. Untuk menentukan perbezaan kepuasan hidup antara pelajar lelaki dan perempuan.

\section{Hipotesis}

Ho1: Tiada perkaitan signifikan antara kemurungan dengan kepuasan hidup dalam kalangan pelajar.

Ho2: Tiada perkaitan signifikan antara keamatan sokongan sosial daripada keluarga dengan kepuasan hidup dalam kalangan pelajar.

Ho3: Tiada perkaitan signifikan antara keamatan sokongan sosial daripada kawan dengan kepuasan hidup dalam kalangan pelajar.

Ho4: Tiada perkaitan signifikan antara keamatan sokongan sosial daripada orang yang penting dengan kepuasan hidup dalam kalangan pelajar.

Ho5: Tiada perbezaan signifikan dalam kepuasan hidup antara pelajar lelaki dan perempuan.

\section{Metod Kajian}

Kajian ini memilih reka bentuk kajian kuantitatif untuk memperoleh dan mengumpul data yang diperlukan. Selain itu, kaedah korelasi Pearson dan ujian t juga digunakan dalam kajian ini. Kaedah korelasi Pearson digunakan bertujuan untuk menentukan perkaitan antara pemboleh ubah bebas iaitu kemurungan dan keamatan sokongan sosial (sokongan keluarga, sokongan kawan, sokongan orang yang penting) dan pemboleh ubah bersandar iaitu kepuasan hidup. Manakala, kaedah ujian t digunakan untuk melihat perbezaan jantina terhadap kepuasan hidup. Di samping itu, teknik tinjauan dengan menggunakan borang soal selidik yang dibentuk juga digunakan dalam kajian ini untuk mengumpul maklumat daripada pelajar universiti di Selangor, Malaysia.

Populasi yang dipilih dalam kajian ini adalah merupakan pelajar yang mengikuti bidang aliran sains tulen sahaja di universiti di Selangor, Selangor, Malaysia. Populasi pelajar yang mengambil bidang aliran sains tulen ialah sebanyak 8883. Responden terdiri daripada golongan pelajar lelaki dan perempuan daripada pelbagai umur, jantina, bangsa, agama dan fakulti. Kajian ini menggunakan persampelan rawak mudah dan saiz sampel ditentukan berdasarkan jadual Krejcie Morgan (1970). Berdasarkan jadual tersebut, saiz sampel yang digunakan ialah 368 orang responden. Penyelidik memilih 4 fakulti aliran sains tulen (fakulti A,B,C dan D) kerana mengandaikan bahawa 4 fakulti sudah memadai untuk mewakili populasi. Setelah mendapat fakulti, penyelidik juga menggunakan persampelan rawak mudah untuk mendapatkan responden di setiap fakulti. Daripada 368 saiz sampel, penyelidik telah membahagikan bilangan tersebut kepada 4 fakulti. Oleh itu, setiap fakulti diwakili oleh 92 orang. Setiap 92 orang merangkumi 40 orang pelajar lelaki dan 52 orang pelajar perempuan. Sebelum mengedarkan borang soal selidik, kebenaran daripada setiap fakulti diperoleh terlebih dahulu dan pelajar juga dijelaskan mengenai etika kerahsiaan. 
Kajian ini menggunakan tiga jenis pengukuran. Beck Depression Inventory (BDI) yang dibangunkan oleh Beck et al. (1961) digunakan untuk mengukur tahap kemurungan pelajar dan nilai alpha bagi kebolehpercayaan instrumen ini ialah 0.94. Skala pengukuran ini mengandungi 21 item dengan skala 4-mata daripada $0=$ "tiada simptom" hingga 3= "simptom teruk". Bagi kajian ini, satu item daripada BDI telah dipadam atas faktor budaya dan perspektif agama di Malaysia (Mukhtar \& Tian, 2008). Manakala bagi keamatan sokongan sosial pelajar, Multidimensional Scale of Perceived Social Support (MSPSS) yang dibangunkan oleh Zimet et al. pada tahun 1988 telah digunakan. Kebolehpercayaan instrumen ini menunjukkan nilai alpha ialah 0.92. Skala ini mengandungi 12 item yang merupakan skala likert 7 -mata bermula daripada $1=$ sangat tidak setuju sehingga $7=$ sangat setuju. Selain itu, skala ini mempunyai tiga sub skala yang terdiri daripada tiga punca sokongan iaitu sokongan keluarga (item $3,4,8,11$ ), sokongan kawan (item 6,7,9,12) dan sokongan orang yang penting (item 1,2,5,10). Akhir sekali, Satisfaction With Life Scale (SWLS) yang dibangunkan oleh Diener et al. (1985) digunakan dalam kajian ini untuk mengukur tahap kepuasan hidup dalam kalangan pelajar. Nilai alpha bagi kebolehpercayaan instrumen ini ialah 0.82 . Skala ini terdiri daripada 5 item dengan skala likert 7-mata bermula $1=$ sangat tidak setuju sehingga $7=$ sangat setuju. Data yang dikumpul kemudiannya dianalisis dengan menggunakan perisian Statistical Package for Social Sciences 23.0 (SPSS).

\section{Analisis Kajian dan Perbincangan}

\section{Analisis Deskriptif Latar Belakang Responden}

Jadual 1 menunjukkan analisis deskriptif bagi latar belakang responden iaitu umur, jantina, bangsa, agama dan fakulti. Berdasarkan Jadual 1, sebanyak 160 atau 43.5\% responden lelaki dan 208 atau $56.5 \%$ responden perempuan telah mengambil bahagian dalam kajian ini. Semua responden adalah terdiri daripada pelajar prasiswazah yang berumur antara 19 tahun hingga 26 tahun. Terdapat 32 (8.7\%) responden yang berumur 19 tahun, $64(17.4 \%)$ responden berumur 20 tahun, $84(22.8 \%)$ responden yang berumur 21 tahun, $149(40.5 \%)$ responden yang berumur 22 tahun dan 31(8.4\%) responden yang berumur 23 tahun. Bagi yang berumur 24 tahun, 25 tahun dan 26 tahun pula, terdapat $1(0.3 \%), 5(1.4 \%)$ dan $2(0.5 \%)$ masing-masing. Purata bagi umur responden ialah 21.32 manakala sisihan piawai ialah 1.243. Majoriti responden dalam kajian ini adalah berbangsa Melayu iaitu 310 orang (84.2\%). Manakala bangsa Cina ialah 30 orang (8.2\%), bangsa India ialah 13 (3.5\%) dan lainlain seramai 15 (4.1\%) orang.

Jadual 1: $\quad$ Deskriptif latar belakang responden $(n=368)$

\begin{tabular}{llllll}
\hline Ciri-ciri & n $(\%)$ & Purata & SP. & Min. & Mak. \\
\hline Jantina & & & & & \\
Lelaki & $160(43.5)$ & & & & \\
Perempuan & $208(56.5)$ & & & & \\
& & & & \\
Umur (tahun) & & 21.32 & 1.243 & & \\
19 & $32(8.7)$ & & & \\
20 & $64(17.4)$ & & & \\
21 & $84(22.8)$ & & & \\
22 & $149(40.5)$ & & & \\
23 & $31(8.4)$ & & & \\
24 & $1(0.3)$ & & & \\
25 & $5(1.4)$ & & & \\
26 & $2(0.5)$ & & & \\
\end{tabular}




\begin{tabular}{llll}
\hline Bangsa & & & \\
Melayu & $310(84.2)$ & & \\
Cina & $30(8.2)$ & & \\
India & $13(3.5)$ & & \\
Lain-lain & $15(4.1)$ & & \\
& & 3.022 & \\
Tahun Pengajian & & & \\
Tahun 1 & $41(11.1)$ & & \\
Tahun 2 & $68(18.5)$ & & \\
Tahun 3 & $111(30.2)$ & & \\
Tahun 4 & $147(39.9)$ & & \\
Tahun 5 & $1(0.3)$ & & \\
& & & \\
Fakulti & $92(25.0)$ & & \\
A & $92(25.0)$ & \\
B & $92(25.0)$ & \\
C & $92(25.0)$ & \\
D &
\end{tabular}

Nota: $\mathrm{SP}=$ Sisihan Piawai, Min $=$ Minimum, Mak $=$ Maksimum

Bagi tahun pengajian, sebanyak $41(11.1 \%)$ orang responden daripada Tahun 1, 68 (18.5\%) orang responden daripada Tahun 2 dan Tahun 3 adalah seramai $111(30.2 \%)$ orang. Selain itu, bilangan responden daripada Tahun 4 adalah paling tinggi iaitu 147 (39.9\%) orang dan Tahun 5 hanya mempunyai seorang $(0.3 \%)$ responden sahaja. Purata tahun pengajian responden ialah 3.00 dan sisihan piawai ialah 1.022. Akhir sekali, kajian ini memilih hanya empat buah fakulti sahaja untuk melaksanakan kajian ini iaitu Fakulti A, B, C dan D. Setiap fakulti mempunyai 92 (25.0\%) responden sahaja. Hal ini demikian kerana 4 buah fakulti dianggarkan memadai untuk mewakili populasi.

\section{Analisis Deskriptif Tahap Kemurungan}

Berdasarkan Jadual 2, 18 orang responden atau 4.9\% dikategorikan tiada kemurungan. Kebanyakan responden berada pada tahap normal iaitu $42.4 \%(n=156) .19 .8 \%(n=73)$ responden berada pada tahap mild mood disturbance, $10.6 \%(\mathrm{n}=39)$ responden berada pada tahap borderline clinical depression dan $15.8 \%(\mathrm{n}=58)$ responden berada pada tahap moderate depression. Seterusnya, $4.9 \%(\mathrm{n}=18)$ responden dikategorikan mempunyai tahap severe depression dan hanya $1.6 \%(n=6)$ responden mempunyai tahap extreme depression. Secara keseluruhannya, skor purata tahap kemurungan responden bagi skala BDI ialah 3.11 dengan sisihan piawai 1.432.

Jadual 2: Deskriptif Tahap Kemurungan ( $\mathrm{n}=368)$

\begin{tabular}{llllll}
\hline Pembolehubah & n (\%) & Purata & SP & Min. & Mak. \\
\hline Kemurungan & & 3.11 & 1.432 & 1 & 7 \\
$\quad$ No depression & $18(4.9)$ & & & & \\
Normal & $156(42.4)$ & & & & \\
Mild mood disturbance & $73(19.8)$ & & & & \\
Borderline clinical depression & $39(10.6)$ & & & & \\
Moderate depression & $58(15.8)$ & & & & \\
Severe depression & $18(4.9)$ & & & & \\
Extreme depression & $6(1.6)$ & & & & \\
\hline
\end{tabular}

Nota: $\mathrm{SP}=$ Sisihan piawai, Min $=$ Minimum, Mak $=$ Maksimum 


\section{Analisis Deskriptif Tahap Keamatan Sokongan Sosial (Sokongan Keluarga, Sokongan Kawan dan Sokongan Orang Yang Penting)}

Keamatan sokongan sosial keluarga, kawan dan orang yang penting bagi kajian ini merupakan sub skala daripada skala pengukuran Multidimensional Scale of Perceived Social Support (MSPSS). Item 3,4,8 dan 11 dalam MSPSS merupakan item bagi keamatan sokongan sosial keluarga manakala item 6,7,9 dan 12 adalah item bagi sokongan kawan dan item 1,2,5 dan 10 adalah item sokongan sosial daripada orang yang penting. Bagi setiap sub skala keamatan sokongan sosial ini, tahap sokongan sosial responden ditentukan melalui skor purata bagi 4 item tertentu kemudian dikategorikan kepada tiga tahap sokongan iaitu sokongan rendah, sokongan sederhana dan sokongan tinggi. Berdasarkan jadual di atas, kebanyakan responden mempunyai sokongan tinggi bagi keamatan sokongan sosial (keluarga) iaitu 55.7\% $(\mathrm{n}=205)$ diikuti oleh sokongan sederhana $37 \%(\mathrm{n}=136)$ dan sokongan rendah $7.3 \%(n=27)$.

Jadual 3: Deskriptif Tahap Keamatan Sokongan Sosial $(\mathrm{n}=368)$

\begin{tabular}{llllll}
\hline Pembolehubah & n (\%) & Purata & SP & Min. & Mak. \\
\hline $\begin{array}{l}\text { Sokongan sosial keluarga } \\
\quad \text { Sokongan rendah }\end{array}$ & & 2.48 & 0.631 & 1 & 3 \\
$\quad \begin{array}{l}\text { Sokongan sederhana } \\
\text { Sokongan tinggi }\end{array}$ & $\begin{array}{l}27(7.3) \\
136(37.0)\end{array}$ & & & & \\
& $205(55.7)$ & & & & \\
Sokongan sosial kawan & & 2.42 & 0.696 & 1 & 3 \\
$\quad$ Sokongan rendah & $44(12.0)$ & & & & \\
$\quad \begin{array}{l}\text { Sokongan sederhana } \\
\text { Sokongan tinggi }\end{array}$ & $126(34.2)$ & & & & \\
& $198(53.8)$ & & & \\
$\begin{array}{l}\text { Sokongan sosial orang } \\
\text { yang penting }\end{array}$ & & 2.42 & 0.722 & 1 & 3 \\
$\quad \begin{array}{l}\text { Sokongan rendah } \\
\text { Sokongan sederhana }\end{array}$ & $\begin{array}{l}51(13.9) \\
\quad \text { Sokongan tinggi }\end{array}$ & & & & \\
\hline
\end{tabular}

Nota: $\mathrm{SP}=$ Sisihan piawai, Min $=$ Minimum, Mak $=$ Maksimum

Kemudian bagi keamatan sokongan sosial (kawan) pula, kebanyakan responden juga mempunyai tahap sokongan tinggi iaitu 53.8\% ( $\mathrm{n}=198)$, diikuti oleh sokongan sederhana $34.2 \%(\mathrm{n}=126)$ dan sokongan rendah $12 \%(n=44)$. Akhir sekali, kebanyakan responden juga mempunyai tahap sokongan yang tinggi bagi keamatan sokongan sosial (orang yang penting). Berdasarkan Jadual 3, tahap sokongan tinggi ialah 55.4\% $(\mathrm{n}=204)$ diikuti oleh tahap sederhana iaitu 30.7\% $(\mathrm{n}=113)$ dan tahap sokongan rendah ialah $13.9 \%(\mathrm{n}=51)$. Antara ketiga-tiga jenis sokongan sosial ini, keamatan sokongan sosial (keluarga) menunjukkan skor purata yang paling tinggi iaitu 2.48 dengan sisihan piawai 0.631 . Kemudian skor purata diikuti oleh keamatan sokongan sosial (kawan) iaitu 2.42 dengan sisihan piawai 0.696 dan skor purata keamatan sokongan sosial (orang yang penting) ialah 2.42 dengan sisihan piawai 0.722. Secara keseluruhannya, kebanyakan responden mendapat sokongan sosial daripada keluarga lebih tinggi berbanding sokongan sosial yang lain. Daripada hasil kajian ini juga, penyelidik mendapati bahawa kebanyakan responden mendapat lebih dari satu jenis sokongan sosial.

\section{Analisis Deskriptif Tahap Kepuasan Hidup}

Kepuasan hidup responden ditentukan oleh jumlah skala penuh responden kemudian dibahagikan kepada 7 kategori. Jadual 4 menunjukkan hasil analisis deskriptif bagi skala SWLS. Hasil analisis deskriptif mendapati bahawa kebanyakan responden berasa 'sedikit berpuas hati' dengan kehidupan mereka iaitu $28.3 \%(\mathrm{n}=104)$. Kemudian, responden yang berasa 'berpuas hati' ialah sebanyak $25.3 \%$ $(\mathrm{n}=93)$ dan 'sangat berpuas hati' ialah $10.1 \%(\mathrm{n}=37)$. 
DOI: https://doi.org/10.47405/mjssh.v5i6.426

Jadual 4: Deskriptif Tahap Kepuasan Hidup Responden ( $\mathrm{n}=368)$

\begin{tabular}{llllll}
\hline Pembolehubah & $\mathbf{n}(\%)$ & Purata & SP & Min. & Mak. \\
\hline Keamatan kepuasan hidup & & 4.62 & 1.648 & 1 & 7 \\
Sangat tidak berpuas hati & $15(4.1)$ & & & & \\
Tidak berpuas hati & $32(8.7)$ & & & & \\
Sedikit tidak berpuas hati & $65(17.7)$ & & & & \\
Neutral & $22(6.0)$ & & & & \\
Sedikit berpuas hati & $104(28.3)$ & & & & \\
Berpuas hati & $93(25.3)$ & & & & \\
Sangat berpuas hati & $37(10.1)$ & & & & \\
\hline
\end{tabular}

Nota: $\mathrm{SP}=$ Sisihan piawai, Min $=$ Minimum, Mak $=$ Maksimum

Responden yang mempunyai tahap 'neutral' bagi kepuasan hidup ialah sebanyak $6.0 \%(\mathrm{n}=22), 17.7 \%$ $(\mathrm{n}=65)$ bagi responden yang berasa 'sedikit tidak berpuas hati' dan $8.7 \%(\mathrm{n}=32)$ bagi yang 'tidak berpuas hati'. Akhir sekali, responden yang berasa 'sangat tidak berpuas hati' dengan kehidupan mereka ialah sebanyak 4.1\% $(\mathrm{n}=15)$. Secara keseluruhannya, skor purata bagi skala SWLS dalam kajian ini ialah 4.62 dengan sisihan piawai 1.648.

\section{Ho1: Tiada perkaitan signifikan antara kemurungan dengan kepuasan hidup dalam kalangan pelajar.}

Ujian korelasi Pearson telah digunakan untuk menentukan perkaitan antara kemurungan dengan kepuasan hidup dalam kalangan pelajar universiti. Hasil ujian menunjukkan bahawa terdapat perkaitan signifikan antara kemurungan dengan kepuasan hidup $(\mathrm{r}=-0.598, \mathrm{p}=0.000)$. Nilai korelasi Pearson negatif bagi kemurungan menunjukkan bahawa semakin rendah kemurungan, semakin tinggi kepuasan hidup pelajar. Jadi, Hol ditolak dalam analisis ini. Perkara ini menunjukkan bahawa kemurungan mempengaruhi kepuasan hidup dalam kalangan pelajar.

Jadual 5: Korelasi Pearson antara kemurungan dengan kepuasan hidup $(\mathrm{n}=368)$

\begin{tabular}{ccc}
\hline \multirow{2}{*}{ Pembolehubah } & \multicolumn{2}{c}{ Kepuasan Hidup } \\
\cline { 2 - 3 } & $\mathbf{r}$ & $\mathbf{p}$ \\
\hline Kemurungan & $-0.598^{* *}$ & 0.000 \\
\hline
\end{tabular}

Nota: $* * \mathrm{p} \leq 0.01$

Dapatan analisis ini disokong oleh kajian yang dilakukan oleh Guney, Kalafat dan Boysan (2010) yang mendapati bahawa terdapat perkaitan signifikan antara kemurungan dengan kepuasan hidup dan berkorelasi secara negatif. Dapatan kajian ini membuktikan bahawa pelajar universiti cenderung untuk mempunyai kepuasan hidup yang tinggi jika mereka yang mempunyai kemurungan yang rendah. Dengan kata lain, pelajar yang mempunyai kemurungan cenderung untuk menilai hidup mereka dengan penilaian yang rendah atau berasa tidak puas hati dengan kehidupan mereka.

\section{Ho2: Tiada perkaitan signifikan antara keamatan sokongan sosial daripada keluarga dengan kepuasan hidup dalam kalangan pelajar.}

Ujian korelasi Pearson telah digunakan untuk menentukan perkaitan antara keamatan sokongan sosial (sokongan keluarga, sokongan kawan, sokongan orang yang penting) dalam kalangan pelajar universiti. Analisis kajian dalam Jadual 6 menunjukkan bahawa terdapat perkaitan signifikan antara keamatan sokongan sosial (sokongan keluarga) dengan kepuasan hidup dalam kalangan pelajar universiti $(r=0.534, p=0.000)$. Selain itu, nilai positif korelasi menunjukkan bahawa semakin tinggi keamatan sokongan sosial (sokongan keluarga), semakin tinggi kepuasan hidup. Maka, Ho2 ditolak. 
Malaysian Journal of Social Sciences and Humanities (MJSSH), Volume 5, Issue 6, (page 68 - 78), 2020

DOI: https://doi.org/10.47405/mjssh.v5i6.426

Jadual 6: Korelasi Pearson antara keamatan sokongan sosial dengan kepuasan hidup ( $\mathrm{n}=368)$

\begin{tabular}{ccc}
\hline Pembolehubah & \multicolumn{2}{c}{ Kepuasan Hidup } \\
\cline { 2 - 3 } & $\mathrm{r}$ & $\mathrm{p}$ \\
\hline $\begin{array}{c}\text { Keamatan Sokongan Sosial } \\
\text { (Keluarga) }\end{array}$ & $0.534^{* *}$ & 0.000 \\
\hline
\end{tabular}

Nota: **p $\leq 0.01$

Perkara ini bermaksud keamatan sokongan sosial (sokongan keluarga) boleh mempengaruhi kepuasan hidup. Hasil kajian ini disokong oleh kajian yang dilakukan oleh Harikandei (2017) yang mendapati bahawa sokongan sosial daripada keluarga mempunyai perkaitan signifikan dengan kepuasan hidup dalam kalangan pelajar universiti. Dengan kata lain, pelajar universiti cenderung untuk mempunyai kepuasan hidup yang tinggi jika mereka mempunyai keamatan sokongan sosial yang tinggi daripada keluarga. Mereka juga akan menilai kehidupan mereka dengan penilaian yang tinggi dengan adanya sokongan sosial tersebut.

\section{Ho3: Tiada perkaitan signifikan antara keamatan sokongan sosial daripada kawan dengan kepuasan hidup dalam kalangan pelajar.}

Berdasarkan Jadual 7, hasil kajian menunjukkan bahawa terdapat perkaitan signifikan antara keamatan sokongan sosial (sokongan kawan) dengan kepuasan hidup $(\mathrm{r}=0.399, \mathrm{p}=0.000)$. Tambahan lagi, nilai positif korelasi menunjukkan bahawa semakin tinggi keamatan sokongan sosial daripada kawan, semakin tinggi kepuasan hidup. Maka, Ho3 ditolak. Perkara ini membawa maksud bahawa keamatan sokongan sosial (sokongan kawan) boleh mempengaruhi kepuasan hidup pelajar. Hasil kajian ini mempunyai persamaan dengan kajian lepas di mana keamatan sokongan sosial daripada kawan berkorelasi secara positif dengan kepuasan hidup dalam kalangan pelajar (Nauffal, D \& Sbeity, 2013). Dalam kata lain, keamatan sokongan sosial tinggi daripada kawan menyumbang kepada tingginya kepuasan hidup dalam kalangan pelajar universiti.

Jadual 7: Korelasi Pearson antara keamatan sokongan sosial dengan kepuasan hidup $(\mathrm{n}=368)$

\begin{tabular}{ccc}
\hline Pembolehubah & \multicolumn{2}{c}{ Kepuasan Hidup } \\
\cline { 2 - 3 } & $\mathrm{r}$ & $\mathrm{p}$ \\
\hline $\begin{array}{c}\text { Keamatan Sokongan Sosial } \\
\text { (Kawan) }\end{array}$ & $0.399^{* *}$ & 0.000 \\
\hline
\end{tabular}

Nota: $* * \mathrm{p} \leq 0.01$

\section{Ho4: Tiada perkaitan signifikan antara keamatan sokongan sosial daripada orang yang penting dengan kepuasan hidup dalam kalangan pelajar.}

Bagi hipotesis yang terakhir bagi objektif 2, hasil kajian dalam Jadual 8 menunjukkan bahawa terdapat perkaitan signifikan antara keamatan sokongan sosial daripada orang yang penting dengan kepuasan hidup $(\mathrm{r}=0.421, \mathrm{p}=0.000)$. Manakala, nilai positif korelasi menunjukkan semakin tinggi keamatan sokongan sosial daripada orang yang penting, semakin tinggi kepuasan hidup. Maka, Ho4 ditolak. Hal ini bermaksud bahawa keamatan sokongan sosial daripada orang yang penting mempengaruhi kepuasan hidup pelajar. Kajian ini mempunyai persamaan dengan kajian yang dilakukan oleh Othman (2011) di mana keamatan sokongan sosial daripada orang yang penting menyumbang kepada kepuasan hidup. Perkara ini membuktikan bahawa keamatan sokongan sosial yang tinggi daripada orang yang penting menyumbang kepada kepuasan hidup yang tinggi. Kesimpulannya, keamatan sokongan sosial (sokongan keluarga) merupakan faktor yang paling kuat mempengaruhi kepuasan hidup dalam kalangan pelajar. Hal ini demikian kerana keamatan sokongan sosial (sokongan keluarga) mempunyai nilai korelasi Pearson yang paling tinggi iaitu 0.534 . 
DOI: https://doi.org/10.47405/mjssh.v5i6.426

Jadual 8: Korelasi Pearson antara keamatan sokongan sosial dengan kepuasan hidup $(\mathrm{n}=368)$

\begin{tabular}{ccc}
\hline Pembolehubah & \multicolumn{3}{c}{ Kepuasan Hidup } \\
\cline { 2 - 3 } & $\mathrm{r}$ & $\mathrm{p}$ \\
\hline $\begin{array}{c}\text { Keamatan Sokongan Sosial } \\
\text { (Orang yang penting) }\end{array}$ & $0.421^{* *}$ & 0.000 \\
\hline
\end{tabular}

Nota: **p $\leq 0.01$

\section{Ho5: Tiada perbezaan signifikan dalam kepuasan hidup antara pelajar lelaki dan perempuan.}

Hasil analisis ujian $\mathrm{t}$ dalam Jadual 9 menunjukkan bahawa tiada perbezaan signifikan dalam kepuasan hidup antara pelajar lelaki dan perempuan $(\mathrm{t}=1.548, \mathrm{p}=0.123)$. Skor min bagi pelajar lelaki ialah 23.16 manakala skor min bagi pelajar perempuan ialah 22.10. Maka, Ho5 gagal ditolak. Hasil kajian ini selari dengan kajian yang dilakukan oleh Demirbatir et al. (2013) dan Bijandi (2018) yang mendapati bahawa tiada perbezaan signifikan antara pelajar lelaki dan pelajar perempuan dalam kepuasan hidup. Perkara ini menunjukkan bahawa faktor jantina tidak mempengaruhi kepuasan hidup.

Jadual 9: Perbezaan kepuasan hidup antara pelajar lelaki dan perempuan $\quad(n=368)$

\begin{tabular}{lccc}
\hline \multirow{2}{*}{ Pembolehubah } & \multicolumn{3}{c}{ Kepuasan Hidup } \\
\cline { 2 - 4 } & Purata & $\mathrm{t}$ & $\mathrm{p}$ \\
\hline Jantina & & 1.548 & 0.123 \\
Lelaki & 23.16 & & \\
Perempuan & 22.09 & & \\
\hline
\end{tabular}

Nota: **p $<0.05$

Namun begitu, kajian yang dilakukan oleh Bukhari dan Saba (2017) mendapati bahawa pelajar perempuan mempunyai tahap kepuasan hidup yang lebih tinggi berbanding pelajar lelaki manakala kajian yang dilakukan oleh Kapur dan Khosla (2013) mendapati pelajar lelaki mempunyai tahap kepuasan hidup lebih tinggi berbanding pelajar perempuan. Perkara ini mungkin disebabkan oleh kajian-kajian tersebut dijalankan di luar negara dan ada faktor lain yang mempengaruhi kepuasan hidup. Sebagai contohnya, faktor status ekonomi pelajar tersebut dan faktor budaya. Ketidaksamaan hasil kajian ini boleh menjadi sebab untuk meneroka dengan lebih lanjut mengenai perbezaan pelajar lelaki dan perempuan dalam kepuasan hidup dalam penyelidikan pada masa hadapan.

\section{Implikasi}

Hasil kajian ini menunjukkan bahawa kemurungan dan keamatan sokongan sosial (sokongan keluarga, sokongan kawan, sokongan orang yang penting) sangat berkait rapat dengan kepuasan hidup. Seorang pelajar perlu bijak mengawal emosi dan tekanan ketika menghadapi pelbagai cabaran. Hasil kajian ini dapat meningkatkan kesedaran kepada pelajar mengenai pentingnya penguasaan emosi dan pengawalan kendiri agar tidak terdedah kepada kemurungan dan seterusnya dapat meningkatkan kepuasan hidup.

Selain itu, hasil kajian ini juga sangat penting kepada institusi sosial terutamanya keluarga kerana keluarga merupakan golongan yang paling dekat dengan seseorang pelajar. Sebagai seorang pelajar universiti yang sedang menghadapi pelbagai cabaran, mereka sentiasa memerlukan sokongan sosial daripada persekitaran mereka. Kajian ini boleh memberi kesedaran kepada ahli keluarga terutamanya para ibu bapa atau bakal ibu bapa untuk sentiasa mengambil berat dan memahami anak-anak mereka. Kepuasan hidup seorang pelajar akan meningkat kerana keamatan sokongan sosial merupakan faktor kepada kepuasan hidup. Seterusnya, kajian mengenai kepuasan hidup sudah pasti dapat memberi sumbangan kepada dunia penyelidikan di Malaysia. Hal ini demikian kerana kajian sedia ada tentang 
kepuasan hidup banyak dilaksanakan di negara-negara luar seperti Eropah, Amerika Syarikat dan negara lain. Kajian ini amat penting kerana budaya dan gaya hidup di Malaysia adalah berbeza dengan negara-negara lain.

Selain itu, berdasarkan hasil kajian ini, kemurungan didapati mempunyai perkaitan signifikan dengan kepuasan hidup. Dengan kata lain, kepuasan hidup boleh terjejas jika tahap kemurungan tinggi. Walaupun kebanyakan pelajar yang terlibat dalam kajian ini berada pada tahap normal kemurungan, namun masih ada pelajar yang mempunyai tahap kemurungan yang teruk dan melampau. Hasil kajian ini boleh menggalakkan pihak universiti untuk menyediakan program-program berbentuk motivasi secara berterusan kepada para pelajar sebagai contohnya program motivasi yang berjudul "Happy Mind". Hal ini demikian supaya para pelajar sentiasa menyedari betapa pentingnya mengekalkan minda yang sihat agar dapat mencapai kepuasan dalam hidup mereka walaupun ketika menghadapi tekanan hidup.

Bukan sahaja pihak universiti, kajian mengenai kepuasan hidup juga boleh memberi input kepada para profesional seperti kaunselor, ahli psikologi atau ahli akademik untuk menyediakan terapi minda supaya dapat meningkatkan kepuasan hidup pelajar. Kajian ini menunjukkan bahawa kebanyakan pelajar berada pada tahap sedikit berpuas hati dengan kehidupan mereka jadi masih ada ruang untuk meningkatkan kepuasan hidup. Dengan mengkaji faktor-faktor kepuasan hidup, ianya dapat menimbulkan idea untuk membuat penambahbaikan program yang sedia ada atau melaksanakan program yang relevan kepada para pelajar. Para profesional juga boleh bekerjasama dengan para ibu bapa untuk melaksanakan program tersebut.

\section{Kesimpulan}

Kepuasan hidup bagi setiap pelajar adalah berbeza dan ianya bergantung kepada pelajar tersebut dalam membuat penilaian terhadap hidupnya. Faktor yang mempengaruhi kepuasan hidup pelajar adalah kemurungan dan keamatan sokongan sosial (sokongan keluarga, sokongan kawan, sokongan orang penting). Pelajar yang mempunyai kemurungan boleh menyebabkan kepuasan hidupnya rendah. Oleh itu, keamatan sokongan sosial (sokongan keluarga, sokongan kawan, sokongan orang penting) amat penting dalam kehidupan setiap pelajar kerana dapat meningkatkan kepuasan hidup mereka. Hal ini demikian kerana, keamatan sokongan sosial (sokongan keluarga, sokongan kawan, sokongan orang penting) melibatkan komunikasi dan interaksi antara dua pihak. Para pelajar akan merasakan bahawa mereka sentiasa mendapat sokongan daripada persekitaran mereka. Perkara ini boleh menjauhkan mereka daripada kemurungan dan seterusnya dapat meningkatkan kepuasan hidup mereka.

\section{Rujukan}

Bukhari, S. R., \& Saba, F. (2017). Depression, anxiety and stress as negative predictors of life satisfaction in university students. Rawal Medical Journal, 42(2), 255-257.

Beutel, M. E., Glaesmer, H., Wiltink, J., Marian, H., \& Brähler, E. (2010). Life satisfaction, anxiety, depression and resilience across the life span of men. The Aging Male, 13(1), 32-39.

Demirbatir, E., Helvaci, A., Yilmaz, N., Gul, G., Senol, A., \& Bilgel, N. (2013). The psychological well-being, happiness and life satisfaction of music students. Psychology, 4(11), 16.

Diener, E. D., Emmons, R. A., Larsen, R. J., \& Griffin, S. (1985). The satisfaction with life scale. Journal of personality assessment, 49(1), 71-75.

Guney, S., Kalafat, T., \& Boysan, M. (2010). Dimensions of mental health: life satisfaction, anxiety and depression: a preventive mental health study in Ankara University students population. Procedia-Social and Behavioral Sciences, 2(2), 1210-1213.

Hadi., K. (2011). Social support, social network, and life satisfaction among older adults in Peninsular Malaysia. Disertasi tesis Master yang tidak diterbitkan, Universiti Putra Malaysia, Malaysia.

Harikandei, H. (2017). Relationship between Perceived Social Support, Mental Health and Life Satisfaction in MSc Students of Physical Education. International Journal of Sports Science, 7(4), 159-162. 
Kapur, V., \& Khosla, M. (2013). Subjective well-being and depression: A comparative study among college students. Indian Journal of Positive Psychology, 4(3), 418.

Krejcie, R. V., \& Morgan, D. W. (1970). Determining sample size for research activities. Educational and psychological measurement, 30(3), 607-610.

Malaysia, Kementerian Kesihatan. (2019). Kenyataan Akhbar Ketua Pengarah Kesihatan Malaysia, 10 Oktober 2019. Putrajaya, Kementerian Kesihatan Malaysia. http://www.moh.gov.my/index.php/database_stores/attach_download/337/ 1246

Nabavi, R. T. (2014). Predictors of life satisfaction among Iranian undergraduate students in Malaysian private universities. Disertasi tesis Master yang tidak diterbitkan, Universiti Putra Malaysia.

Nabavi, R. T., Bijandi, M. S. (2018). An Investigation of Predictors of Life Satisfaction among Overseas Iranian Undergraduate Students. Educational Process: International Journal, 7(1), 7493.

Nauffal, D. A. D., \& Sbeity, R. (2013). The role of perceived social support in predicting subjective well-being in Lebanese college students. Happiness \& Well-Being, 116.

Othman, A. K. (2011). An Early Study On Perceived Social Support And Psychological Adjustment Among International Students: The Case Of A Higher Learning Institution In Malaysia. International Journal of Business \& Society, 12(2).

Pavot, W., \& Diener, E. (1993). The affective and cognitive context of self-reported measures of subjective well-being. Social Indicators Research, 28(1), 1-20.

Pavot, W., \& Diener, E. (2008). The satisfaction with life scale and the emerging construct of life satisfaction. The Journal of Positive Psychology, 3(2), 137-152.

Pavot, W., \& Diener, E. (2009). Review of the satisfaction with life scale. In Assessing well-being (pp. 101-117). Springer,Dordrecht.

Rahimah Abdullah (2018). Masalah mental kalangan remaja membimbangkan -kajian. http:/www.astroawani.com/berita-malaysia/masalah-mental-kalangan-remaja-membimbangkankajian 187766 ?amp $=1$

Ramli $^{1}$, S. A., Samah, B. A., Samah, A. A., Idris, K., \& Shaffril ${ }^{1}$, H. A. M. (2017). Urban Youth Subjective Well-Being in Malaysia: Potential Factors. International Journal of Academic Research in Business and Social Sciences, 7(4), 2222-6990.

Shahyad, S., Besharat, M. A., Asadi, M., Alipour, A. S., \& Miri, M. (2011). The relation of attachment and perceived social support with life satisfaction: structural equation model. Procedia-Social and Behavioral Sciences, 15, 952-956.

Zimet, G. D., Dahlem, N. W., Zimet, S. G., \& Farley, G. K. (1988). The multidimensional scale of perceived social support. Journal of personality assessment, 52(1), 30-41. 